\title{
Towards net zero energy modular housing: a case study
}

\author{
Caroline HACHEM-VERMETTE ${ }^{1}$, Chinyere DARA ${ }^{2}$ and Rhys KANE ${ }^{3 *}$ \\ ${ }^{1}$ Assistant Professor, Faculty of Environmental Design, University of Calgary \\ ${ }^{2}$ PhD candidate, Faculty of Environmental Design, University of Calgary \\ ${ }^{3}$ Ladacor Advanced Modular Systems, Canada \\ *Corresponding author's e-mail: caroline.hachem@ucalgary.ca
}

\begin{abstract}
The paper summarizes an investigation of the performance of container based housing units developed by Ladacor Ltd, and compares this performance to traditional housing constructed according to existing standards and codes. The results indicate that the case study housing system can reduce thermal loads (heating and cooling) by about $57 \%$ as compared to the same house designed according to the code. Implementing additional efficiency measures and solar design strategies such as increased south window size, suitable shading devices, thermal mass, and more airtight construction, leads to improved performance. This enhanced scenario can reduce the thermal load by $72 \%$ as compared to the code scenario and by about $35 \%$ as compared to the original case study system.

Achieving a net-zero energy status can be reached by integrating photovoltaics on the south roof of the single-family housing designed with Ladacor roof, assuming energy efficient appliances, lighting and domestic hot water. The optimal case can reach a net positive energy status, with a PV system integrated on the south facing roof surface. Results from this investigation can serve in developing innovative design concepts and guidelines for the design of low cost, self-sufficient modular housing.
\end{abstract}

\section{KEYWORDS}

Shipping container, modular housing, energy modelling, energy efficiency, building envelope

\section{INTRODUCTION}

Employing prefabrication in the construction of houses offers a means for improved energy efficiency and reduced cost of these houses (e.g. Dumas et al. 2016; Ganiron 2016). In fact, studies carried by Canada Mortgage and Housing Corporation (CMHC 2016) indicate that prefabricated houses allow about $55 \%$ savings in cost, and $43 \%$ reduction in carbon dioxide (CO2) emissions over site-built houses.

Modular method of construction, as a form of prefabrication has several advantages such as: reduced construction time and landfill waste, improved indoor air quality through environmental friendly materials, better performing envelope, improved energy performance, and possibility for material recycle and reuse (Lim et al. 2013; Ganiron and Almarwae 2014). Amongst the most recent forms of modular housing gaining popularity in the construction industry is the application 
of shipping containers as building blocks. A number of research studies point to the potential of achieving affordable, energy efficient modular structures employing container-based structures (see for e.gs; Slawik, et al. 2010; Robinson et al. 2011; Bernardo et al. 2013; Lim et al. 2013; and Ganiron and Almarwae 2014). The main focus of existing research is on ways to improve the thermal performance of container-based structures (Pena and Kurt 2012; Alemdag and Aydin 2015). Nevertheless, research on the utilization of container envelope in the construction of energy efficient buildings is still at its early stage in North America.

The first stage in improving the energy efficiency of the container box is to devise an energy efficient building envelope (Thun and Velikov 2013). Specific envelope design requirements for improved energy efficiency include: high performance windows, airtight construction, high performance thermal insulation, and proper shading devices to control solar heat gain. In lightweight structures, additional strategies are required, such as incorporating phase change materials (PCMs) to improve thermal capacity (Zhou et al. 2012; Xiao et al. 2013).

The study presented in this paper is part of a project developed in collaboration with Ladacor ltd, a Canadian modular construction industry. It investigates the performance of container-based structure for residential buildings, and determines its potential to achieve net-zero energy status in Calgary (AB, Canada). The paper summarizes the investigation of the performance of container based housing units and compares this performance to traditional housing constructed according to Canadian National codes. Results from this investigation can serve in developing innovative design concepts and guidelines for the design of low cost, self-sufficient modular housing.

\section{METHODOLOGY}

The investigated housing unit is a 5-bedroom duplex design provided by Ladacor Ltd. This is a single-story building with a basement floor (see Figure 1 below). The basement floor plan design follows conventional building envelope design specifications in Canada. The containers are not utilized in the basement and foundation wall construction. The main floor design combines four $12.2 \mathrm{~m}$ long container boxes to make a single-family unit. This study adopts a reused Intermodal Steel Building Unit (ISBU) designed with shipping container shell to the International Organization for Standardization (ISO). The total house dimension is thus $12.2 \mathrm{~m}$ in length, 9.75 $\mathrm{m}$ in width, and $2.9 \mathrm{~m}$ in height. Two container boxes are joined horizontally to make a module, and each module is fabricated together at the factory removing one side of the longer exterior wall (see, Fig. 1). The adjoining wall between two container modules (marked as "Marriage wall" in Figure 1) has the same construction and insulating qualities as the exterior walls (as designed by Ladacor).

The first stage of this research consists of designing two reference case models termed hereunder Code case and Ladacor case. The code case building envelope characteristics are developed in compliance with Alberta Building Code (2014) standards, the National Building Code of Canada (2015), recommended for low-rise housing and small buildings in Canada, and the American Society of Heating Refrigeration and Air-Conditioning Engineers (ASHRAE) standard for dwellings (ASHRAE 60.1). For the Ladacor model, the building envelope characteristics are based on specifications and drawing details provided by the company. These reference cases are to serve 
as benchmarks for the comparative analysis of the energy performance. Table 1 summarizes the characteristics of these two cases.

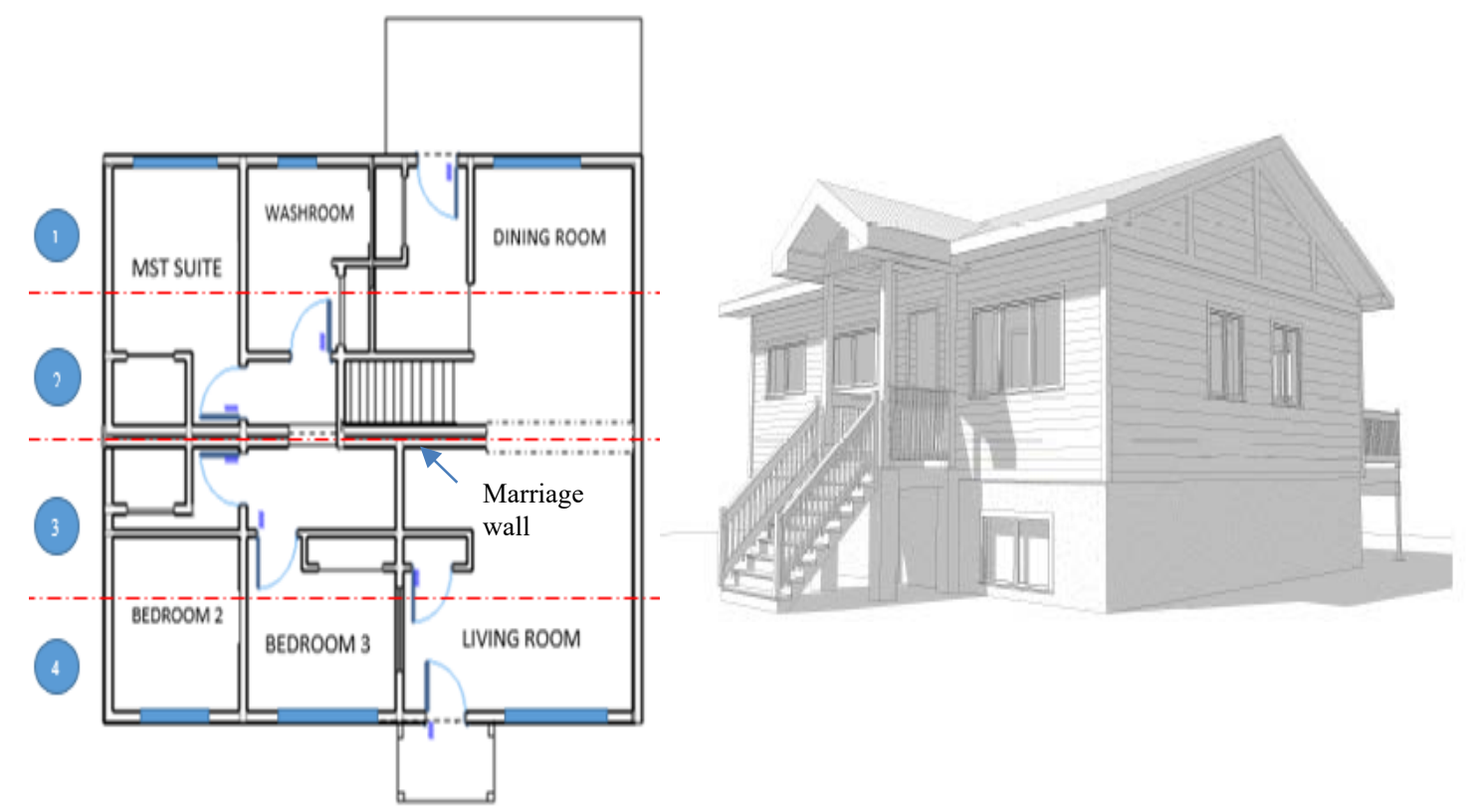

Figure 1. Plan and three-dimensional perspective of 5-bedroom container duplex. Source: Ladacor Advanced Modular Systems 2017.

In the second stage, extensive simulations are conducted employing EnergyPlus in conjunction with Google SketchUp Pluggin to assess the impact of various building envelope components. These include insulation of opaque area, infiltration rate, window assemblies, thermal mass, window size, solar shading controls, phase change material and building orientation, on the overall energy consumption. Results of these simulations are compared to the Ladacor reference model. Potential electricity generation from PV integrated in the roof is then estimated to determine the potential of achieving net zero energy status.

In addition to the building envelope characteristics discussed above, a few assumptions are adopted in the EnergyPlus model. Lighting, people and equipment schedules are set to suit weekly and daily activities. For this study, the infiltration rate of 0.5 ACH (@75 pa) is adopted for the code case based on ASHRAE's recommendation of Average Air tightness (Fennell and Haehnel 2005) while Ladacor case assumes more tight construction of $0.1 \mathrm{ACH}$ (@75pa). Actual tests to verify the air-tightness of the structures are recommended.

The domestic hot water system is estimated to be $1817 \mathrm{KWh} / \mathrm{year}$, based on efficient hot water use, and assuming a consumption of $2.62 \mathrm{KWh} /$ occupant/day (Sartori et al. 2010). This is based on the assumption of hot water usage of $50 \mathrm{~L} /$ day/person. This value is derived from information provided in the literature (e.g. i IEA task 26, EN 15316) and the Canadian EQuilibrium Initiative), with the assumption that it is possible to reduce significantly the daily hot water (DHW) consumption, using different methods (e.g., use of low-flow showerheads). The interior lighting power density is calculated as $5.0 \mathrm{~W} / \mathrm{m}^{2}$ high efficiency LEDs for dwelling units provided by the National Energy Code of Canada for Buildings (Natural Research Council of Canada 2015b). 
Table 1. Code, Ladacor and Optimal Case Building Characteristics

\begin{tabular}{|c|c|c|c|}
\hline \multirow{2}{*}{$\begin{array}{l}\text { Building Envelope } \\
\text { Characteristics }\end{array}$} & \multicolumn{2}{|c|}{ Reference Cases } & \multirow{2}{*}{$\begin{array}{l}\text { Improved Case } \\
\text { Optimal Case }\end{array}$} \\
\hline & Code Case & Ladacor Case & \\
\hline Total Building Area & $237.83 \mathrm{~m}^{2}$ & $237.83 \mathrm{~m}^{2}$ & $237.83 \mathrm{~m}^{2}$ \\
\hline Container floor Area & $118.92 \mathrm{~m}^{2}$ per floor & $118.92 \mathrm{~m}^{2}$ per floor & $118.92 \mathrm{~m}^{2}$ per floor \\
\hline Building Dimensions & $\begin{array}{l}\text { Length } \times \text { Width } \times \text { Height } \\
(12.2 \mathrm{~m} \times 9.75 \mathrm{~m} \times 2.9 \mathrm{~m})\end{array}$ & $\begin{array}{l}\text { Length } \times \text { Width } \times \text { Height } \\
(12.2 \mathrm{~m} \times 9.75 \mathrm{~m} \times 2.9 \mathrm{~m} \\
)\end{array}$ & $\begin{array}{l}\text { Length } \times \text { Width } \times \text { Height } \\
(12.2 \mathrm{~m} \times 9.75 \mathrm{~m} \times 2.9 \mathrm{~m})\end{array}$ \\
\hline $\begin{array}{l}\text { Building Envelope: } \\
\text { Container Floor }\left(\mathrm{K} . \mathrm{m}^{2} / \mathrm{W}\right)\end{array}$ & $\begin{array}{l}\text { Container Wall: RSI } 3.76 \\
\text { Roof: RSI } 3.78 \\
\text { Boundary Floor: RSI } 3.88\end{array}$ & $\begin{array}{l}\text { Container Wall: } \underline{\text { RSI } 5.0} \\
\text { Roof: } \underline{\text { RSI 9.14 }} \\
\text { Boundary Floor: } \underline{\text { RSI } 4.86}\end{array}$ & $\begin{array}{l}\text { Container Wall: } \underline{\text { RSI } 5.0} \\
\text { Roof: RSI 9.14 } \\
\text { Boundary Floor: } \underline{\text { RSI } 1.0} \\
\underline{\text { (without insulation) }}\end{array}$ \\
\hline $\begin{array}{l}\text { Building Envelope: } \\
\text { Basement Floor RSI (K. } \\
\left.\mathrm{m}^{2} / \mathrm{W}\right)\end{array}$ & $\begin{array}{l}\text { Basement Wall: RSI } 4.75 \\
\text { Basement Floor: RSI } 3.54\end{array}$ & $\begin{array}{l}\text { Basement Wall: RSI } 4.75 \\
\text { Basement Floor: RSI } 3.54\end{array}$ & $\begin{array}{l}\text { Basement Wall: RSI } 4.75 \\
\text { Basement Floor: RSI } 3.54\end{array}$ \\
\hline Door & RSI 2.62 & RSI 2.62 & \\
\hline Window Assembly & $\begin{array}{l}\text { Low-e, double paned } \\
\text { glazing } \\
\left.\text { (U-Value } 2.0 \mathrm{~W} / \mathrm{m}^{2} \mathrm{~K}\right)\end{array}$ & $\begin{array}{l}\text { Low-e, triple paned } \\
\text { glazing, argon filled (U- } \\
\left.\text { Value } 1.2 \mathrm{~W} / \mathrm{m}^{2} \mathrm{~K}\right)\end{array}$ & $\begin{array}{l}\text { Low-e, triple paned } \\
\text { glazing, argon filled (high } \\
\underline{\text { SHGC) }}\end{array}$ \\
\hline Air infiltration rate & $0.5 \mathrm{ACH}$ & $\underline{0.5 \mathrm{ACH}}$ & $\underline{0.04 \mathrm{ACH}}$ \\
\hline \multirow[t]{5}{*}{$\begin{array}{l}\text { Above Ground Window- } \\
\text { Wall Ratio [\%] }\end{array}$} & $\begin{array}{l}\text { Total Façade Glazing: } \\
6.4 \%\end{array}$ & $\begin{array}{l}\text { Total Façade Glazing: } \\
6.4 \%\end{array}$ & $\begin{array}{l}\text { Total Façade Glazing: } \\
10 \%\end{array}$ \\
\hline & South Façade: 13\% & South Façade: $13 \%$ & South Façade: $40 \%$ \\
\hline & East Façade: $4.4 \%$ & East Façade: $4.4 \%$ & East Façade: $4.4 \%$ \\
\hline & West Façade: $0 \%$ & West Façade: $0 \%$ & West Façade: $0 \%$ \\
\hline & North Façade: $7.5 \%$ & North Façade: $7.5 \%$ & North Façade: $7.5 \%$ \\
\hline Envelope improvements & NA & NA & $\begin{array}{l}\text { See summary of envelope } \\
\text { improvements in results } \\
\text { discussion below }\end{array}$ \\
\hline
\end{tabular}

\section{RESULTS}

The parameters studied include insulation level, airtightness, thermal mass, window area and orientation, glazing characteristics and shading devices. These parameters are systematically optimized, employing EnergyPlus and their effect on the energy performance are compared to code reference case. A summary of these results is presented below, both for the reference cases and the optimal case.

\section{Reference cases}

Figure 2 presents heating and cooling load for the living area and the basement, of each of the two reference cases (i.e., Ladacor and Code). The results show that the thermal loads of Ladacor model are $57 \%$ less than those of the code scenario. This is due mostly to better-insulated envelope combined with a more airtight construction. The study shows that, increasing the insulation value in the container floor construction leads to an increase in total building thermal loads. In fact, the 
building performs more efficiently with the reduction of insulation between the two floors by a factor of 4 , thereby allowing for greater heat transfer.

Overall, the results demonstrate that the total building thermal loads are dominated by heating loads.

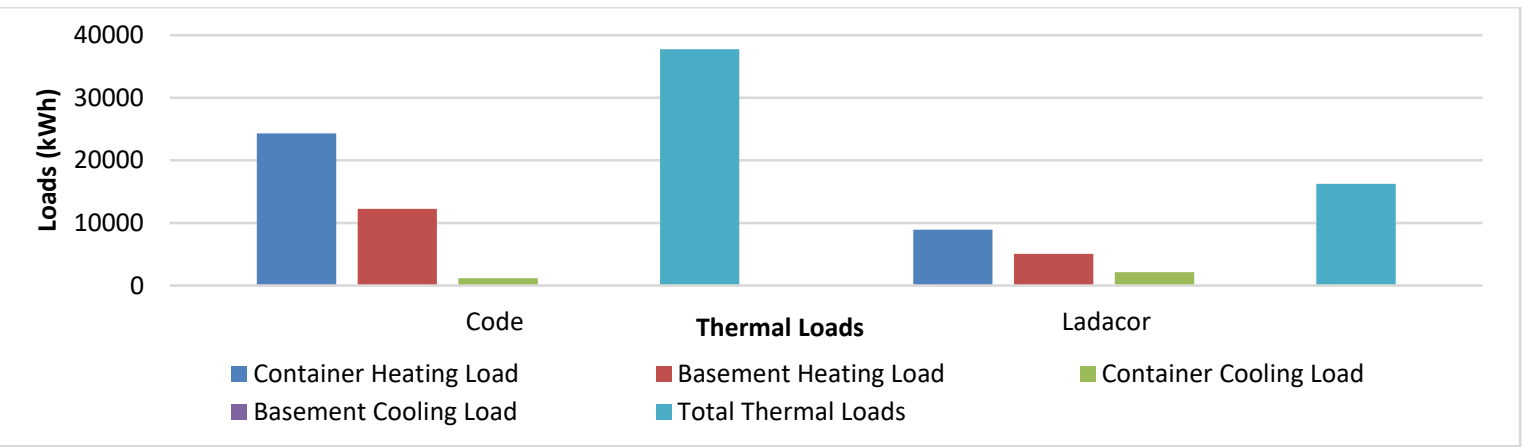

Figure 2. Comparison of reference cases

\section{Envelope Improvements}

The investigation of various design parameters indicates that a number of building envelope upgrades can be implemented to increase the energy efficiency over and above the performance of the Ladacor base case. These improvements include the following:

- Increasing solar heat gain coefficient (SHGC) of the triple pane window assembly.

- Reduction of thermal insulation in the container floor slab construction, by factor of 4 .

- Adding $100 \mathrm{~mm}$ to the container floor slab as thermal mass.

- Assuming increased air-tight construction of 0.6ACH (@50Pa, to conform to passive house design).

- Increasing wall to window ratio of the south facade from $13 \%$ to $40 \%$, to increase the passive solar heat gain potential.

- Adding interior solar blind to windows on all façade as shading control.

- Implementing overhangs on south facing windows to provide additional control of solar radiation.

- Introducing phase change material in the container envelope construction, to increase the thermal mass of the housing unit.

Implementing these upgrades to Ladacor case, results in reducing thermal load by about $72 \%$ as compared to the code case, and 35\% as compared to Ladacor case. These results are presented in Figure 3 below.

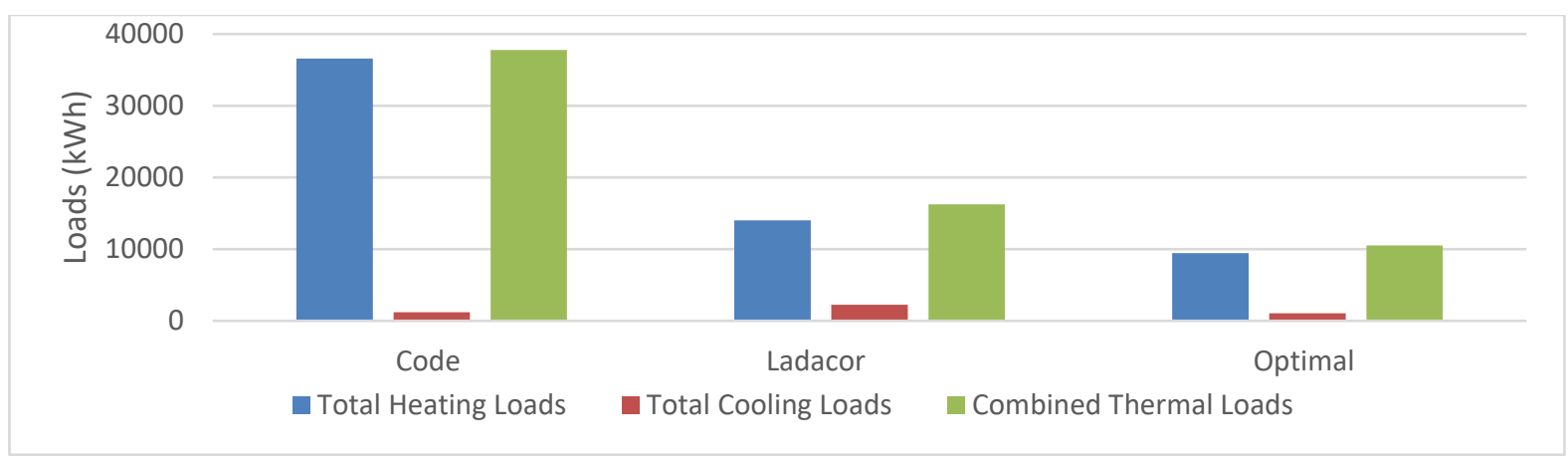


Figure 3. Comparison of thermal loads of envelope scenarios

Assuming that heating and cooling can be delivered to the housing units employing an air source heat pump of COP of 3.3 (that corresponds to commonly found heat pumps), the energy consumed for heating and cooling for the 3 scenarios (code, Ladacor, and optimal) are presented in Figure 4.

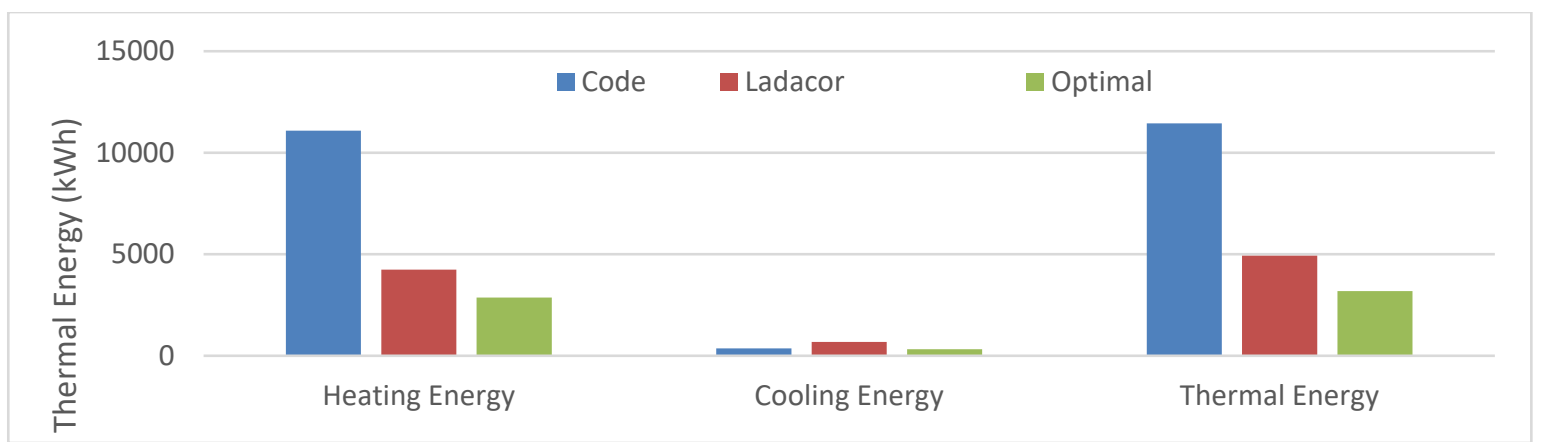

Figure 4. Comparison of energy performance of envelope scenarios

Building Integrated Photovoltaics (BIPV) and Net-Zero Energy Status

A PV system is assumed to be integrated on the total south facing surface of the Ladacor case roof, with the original inclination of the roof (i.e. $22^{0}$ ). For the optimal case, two scenarios of PV tilt angle are analyzed, $30^{\circ}$ and $45^{\circ}$.

The analysis shows that Ladacor and the two scenarios of the optimal case can achieve net zero energy and even energy positive status. The integrated photovoltaic system generates enough electricity to satisfy the building's energy demands for heating, cooling, lighting, electrical appliances, and domestic hot water system. A surplus or net-energy consumption of 5,836 $\mathrm{kWh}$ of electricity per annum is expected with the optimal case designed with $45^{\circ}$ gable roof angle. The results are presented in Figure 5 below.

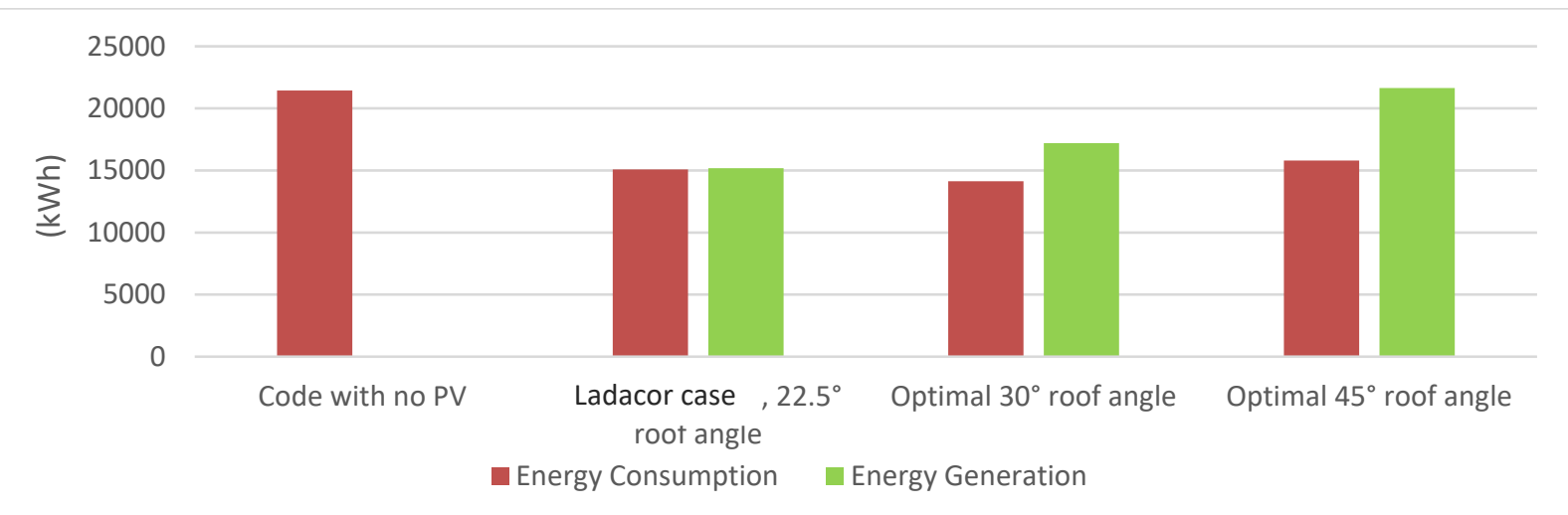

Figure 5. Comparison of net-zero energy status

\section{CONCLUSION}

This study investigates the performance of the container based housing system developed by Ladacor Ltd, and compares this performance to a commonly built housing unit, designed according 
to codes and standards. In addition, various design parameters are investigated to determine design strategies that can increase the energy performance of the studied, container based, single-family housing unit. These parameters are systematically optimized and their effect on the energy performance are compared to code reference case.

The results indicate that Ladacor housing system can reduce thermal loads (heating and cooling) by about $57 \%$ as compared to the same house designed according to the code. Ladacor case assumes an air-tight construction. This assumption is considered due to the continuous nature of the container envelope, which reduces possible leakage in the interface between various surfaces (e.g. walls, ceiling and wall, etc). Future tests to verify the actual air-tightness of the structures are however recommended, as air-tightness plays an important role in the performance of these housing units.

Implementing additional efficiency measures and solar design strategies such as increased south window size, appropriate shading devices, thermal mass, and more air-tight construction, lead to improved performance. This enhanced scenario can reduce the thermal load by $72 \%$ as compared to the code scenario and about $35 \%$ as compared to Ladacor system.

Achieving a net-zero energy status can be reached by integrating photovoltaics on the south roof of the single-family housing unit designed with Ladacor roof, assuming energy efficient appliances, lighting and DHW. The optimal case can reach a net positive energy status, with a PV system integrated at $30^{\circ}$ or $45^{\circ}$ tilt angles.

This study demonstrates that incorporating passive solar design strategies such as optimal insulation levels, thermal mass, and glazing types and sizes, as well as south building orientation can significantly improve the energy performance of such housing systems. This study opens future research areas in life cycle analysis and life cycle costing of container-based units. Understanding the potential environmental impact, in terms of cumulative energy demands (CED), and (GHG) emissions will further indicate the whole life cycle benefit or constraints of containerbased housing.

\section{References}

Alemdag, E. L., \& Aydin, O. (2015). A study of shipping containers as a living space in context of sustainability. Artium, 3 (1), 17-29.

Alberta Building Code (2014). Division B, Part 9 Housing and Small Buildings, volume 2. National Research Council of Canada: Ottawa.

Alberta Energy Efficiency Alliance, (AEEA). (2014). Advancing Energy Efficiency in Calgary.

American Society of Heating Refrigerating and Air-conditioning Engineers, Inc. (ASHRAE) (2007). Standard 90.2-2007 -- Energy Efficient Design of Low-Rise Residential Buildings (ANSI Approved).

Bernardo, L. F. A., Oliveira, L. A. P., Nepomuceno, M. C. S. \& Andrade, J. M. A. (2013). Use of refurbished shipping containers for the construction of housing buildings: Details for the structural project. Journal of Civil Engineering and Management, 19(5), 628-646.

Building Energy Codes (2011). Building technologies program: air leakage guide 2012. Prepared for United States Department of Energy, Energy Efficiency and Renewable Energy. 
Canada Mortgage and Housing Corporation (CMHC). (2016). Using Prefabrication in Housing.https://www.cmhcschl.gc.ca/en/inpr/afhoce/afhoce/afhostcast/afhoid/cote/usprho [Accessed August 17, 2016].

Dumas, A. Trancossi, M. Madonia, M. and Coppola, M. (2014). zero emission temporary habitation: a passive container house acclimatized by geothermal water. Journal of Solar Energy Engineering, Transactions of the ASME, 136(4), pp. 1-8.

EnergyPlus (2017). Weather Data by Location.. U.S Department of Energy's (DOE) Building Technologies Office. [ Accessed February 7, 2017].

Fennell, H. C. \& Haehnel, J. (2005). Setting airtightness standards. American Society of Heating, Refrigerating and Air-Conditioning Engineers, (ASHRAE) Journal, 47: 27-30.

Ganiron, Jr T. U. (2016). Development and efficiency of prefabricated building components. International Journal of Smart Home, 10(6), 85-94.

Ganiron Jr, T. U. \& Almarwae, M. (2014). Prefabricated technology in a modular house. International Journal of Advanced Science and Technology, 73, 51-74.

Hachem, C. Fazio, P. and Athienitis, A. (2013). Solar optimized residential neighborhoods: evaluation and design methodology. Solar Energy, 95, 42-64.

Lim, G. J., Jeong, J. S., Jung, T. H. \& Kim, S. C. (2013). Investigating current status of container housing doi:10.4028/www.scientific.net/AMM.433-435.2282.

National Research Council of Canada. (2015). National Building Code of Canada. Volume 2. Division B: Acceptable solutions, Part 9: Housing and small buildings. Canadian Commission on Building and Fire Codes, National Research Council of Canada: Ottawa

Pena, J. A., \& Kurt, S. (2012). Design of reusable emergency relief housing units using generalpurpose (GP) shipping containers. International Journal of Engineering Research and Innovation, 4 (2), 55-64.

Robinson, A., Austin, S. \& Gibb, A. (2011). Efficiencies in design and manufacturing for construction using shipping containers In: Egbu, C. \& Lou, E.C.W. (Eds.) Procs 27th Annual ARCOM Conference, 5-7 September 2011, Bristol, UK, Association of Researchers in Construction Management, 33-42.

Sartori, I., Candanedo, J., Geier, S., Lollini, R., Garde, F., Athienitis, A., \& Pagliano, L. (2010, September). Comfort and energy efficiency recommendations for net zero energy buildings. In Proceedings of the Eurosun-International Conference on Solar Heating, Cooling and Buildings, Graz, Austria (Vol. 28).

Slawik, H., Bergmann, J., Buchmeier, M. \& Tinney, S. (eds.) (2010). Container Atlas: A Practical Guide to Container Architecture. Gestalten.

Thun, G. and Velikov, k. (2013). North House Climate Responsive Envelope and Control Systems. Chapter 4.3 in F. Trubiano, (ed.) 2013. Design and construction of high performance homes: building envelope, renewable energies and integrated practice. Routledge: New York.

Xiao, W., Wang, X., \& Zhang, Y. (2009). Analytical optimization of interior PCM for energy storage in a lightweight passive solar room. Applied Energy, 86(10), 2013-2018.

Zhou, D., Zhao, C. Y., \& Tian, Y. (2012). Review on thermal energy storage with phase change materials (PCMs) in building applications. Applied energy, 92, 593-605. 